\title{
Yield and Economics of Finger Millet with Different Legumes in Koshi Region of Bihar, India
}

\author{
Binod Kumar ${ }^{1}$ and Pankaj Kumar Ray ${ }^{2 *}$ \\ ${ }^{1}$ Department of Agronomy, MBAC, Saharsa, Bihar, India \\ ${ }^{2}$ Krishi Vigyan Kendra, Saharsa, Bihar, India \\ *Corresponding author
}

\section{A B S T R A C T}

Keywords

Finger millet,

Legumes,

Intercropping,

Yield, Economics

Article Info

Accepted:

18 April 2020

Available Online:

10 May 2020

A field experiment was conducted during the Kharif season of 2019 at Agronomy Instructional Farm, Mandan Bharti Agriculture College, Saharsa, Bihar Agricultural University, Sabour, Bhagalpur, Bihar to evaluate the best finger millet based inter cropping with different legumes. Based on the results, it was concluded that intercropping of finger millet with black gram at 4:2 pair row ratio was distinctly superior among all intercropping system found most profitable by realizing the highest net return. However, yield and yield attributing characters of finger millet were recorded significantly higher in Finger millet intercropped with Black gram followed by groundnut and soybean. . Among the ratio of intercropping system 4:2 ratio of all inter cropping systems recorded higher finger millet equivalent yield along with net income than $6: 2$ ratio of inter cropping system.

\section{Introduction}

Traditional intercropping system is normally followed by many farmers to meet their domestic demands. Selection of crops and cropping systems in relation to soil and climate is a key factor for successful crop production. Intercropping is a system of growing more than one crop species on the same piece of land at the same time. The benefits perceived or realized by intercropping systems include greater land use efficiency improvement in soil fertility. Intern, several factors like cultivar selection, seeding ratios, planting pattern and competition between mixture components affect the growth of species in intercropping (Caballero et al., 1995, Carr et al., 2004). Several legume species including pigeonpea, black gram, groundnut, cowpea, soybean etc. were evaluated for their feasibility as an intercrop. Finger millet (Eleusine coracana L. Ganetn) is one of the important rainfed as well as dry land crop and is widely cultivated 
throughout country in dry tracks with fewer natural resources. Growing of only cereals is not so much remunerative in present scenario of agriculture to fulfill the diverse demand of consumers and rapid growing population. Intercropping of finger millet with different legumes has grater scope to utilize the land and other resources to maximum extent. The productivity of the system can be enhanced by judicious selection of intercrop differing in duration and growth alone in many situations this is supported by Aravazhi et al., (1997), Natarajan (1992) and Sadashiv and Nemgouda (2004).

\section{Materials and Methods}

A field experiment was conducted during the Kharif season of 2019 at Agronomy field unit, Mandan Bharti Agriculture College, Saharsa, Bihar Agricultural University, Sabour, Bhagalpur, Bihar.. The legume crop of Soybean (JS-9752), Black gram (IPU-2-43) and Groundnut (BG-3) were taken as intercrop in finger millet (GPU-67). The intercrops were sown in finger millet in different row proportions of 4: 2 and 6: 2 . The row spacing of finger millet, soybean, black gram and groundnut were maintained at 20 $\mathrm{cm}, 40 \mathrm{~cm}, 30 \mathrm{~cm}$ and $40 \mathrm{~cm}$ respectively .. The legumes crops were sown by dibbling method. The thinning of legume crop was done at 15 days after sowing and only one healthy plant was kept per hill by maintaining the $10 \mathrm{~cm}$ spacing between the two plants. The experiment was laid out in randomized block design with three replications. Ten treatments were studied viz., T1- Sole crop of finger millet, T2- Sole crop of Soybean, T3Sole crop of Black gram, T4- Sole crop of Groundnut, T5- Finger millet + soybean (4:2), T6- Finger millet+ soybean (6:2), T7- Finger millet+ Black gram (4:2), T8 -Finger millet+ Black gram (6:2), T9- Finger millet+ Groundnut (4:2) and T10- Finger millet+ Groundnut (6:2). The gross plot size was $23 \mathrm{x}$ $67 \mathrm{~m}$ and net plot of $6.0 \times 5.40 \mathrm{~m}$. The 5.0 tones of FYM/ ha with recommended dose of fertilizers (60: 40: $25 \mathrm{~kg}$ NPK/ ha) was given to the finger millet crop which was applied through urea and single super phosphate. The crops were sown during the first week of June. Necessary plant protection measures were taken to protect the crop from pest and diseases. The intercultivation two weedings were followed by one hoeing.

\section{Results and Discussion}

\section{Yield attributing characters of finger millet}

Table 1 show that Productive tillers per hill and earhead length of finger millet were significantly high in sole crop. Among different intercroppings systems Finger millet + Black gram (6:2) row ratio were produced higher number of productive tillers per hill (3.500) and earhead length (9.803) of finger millet. It might be due to lower density of finger millet and wider space available for more growth and development of finger millet as compared to other row ratios. Bengali (1987) and Tiwari et al., (2015) reported similar results. Better environment particularly the light interception by outer rows of finger millet in this row ratio lead to higher effective tillers per hill in these treatments or this might be due to development of better complementary relationship and non-renewable resources like water, nutrients and incoming sunlight. These results are in close conformity with the findings of Narasimha Rao et al. (1963) and Divakaran (1967).

The maximum number of ears $/ \mathrm{m}^{2}$ (110.0) was observed in T8- Finger millet + Black gram (6:2) which were at par with T7 -Finger millet + Black gram (4:2). The minimum number of ears $/ \mathrm{m}^{2}$ was 92.0 recorded under T5- Finger millet + Soybean $(4: 2)$.. This was due to more number of productive tillers in T8 compared to others. This was in accordance with earlier finding of Rajesh (2011) in finger millet. 
Table.1 Yield attributing characters of finger millet as influenced by different treatments

\begin{tabular}{|c|c|c|c|c|c|c|c|c|}
\hline Treatments & $\begin{array}{c}\text { No of } \\
\text { productive } \\
\text { tillers/hill }\end{array}$ & $\begin{array}{c}\text { No. of } \\
\text { ears } / \mathrm{m}^{2}\end{array}$ & $\begin{array}{l}\text { Length } \\
\text { of } \\
\text { Ear head } \\
\text { (cm) }\end{array}$ & $\begin{array}{l}\text { Wt. of } \\
\text { ear } \\
\text { head } \\
\text { (gm) }\end{array}$ & $\begin{array}{l}\text { No. of } \\
\text { fingers } \\
\text { /ear }\end{array}$ & $\begin{array}{l}\text { Length of } \\
\text { fingers } \\
\text { /ear }(\mathrm{cm})\end{array}$ & $\begin{array}{c}\text { No. of grains } \\
\text { /ear }\end{array}$ & $\begin{array}{l}\text { Test } \\
\text { wt. } \\
\text { (gm) }\end{array}$ \\
\hline T1- Finger millet ( sole) & 3.600 & 111.00 & 11.000 & 35.10 & 8.100 & 5.600 & 2401 & 3.800 \\
\hline \multicolumn{9}{|l|}{ T2- Soybean (sole) } \\
\hline \multicolumn{9}{|l|}{ T3 -Black gram (sole) } \\
\hline \multicolumn{9}{|l|}{ T4 -Groundnut (sole) } \\
\hline $\begin{array}{l}\text { T5 -Finger millet+ soybean } \\
(4: 2)\end{array}$ & 2.717 & 92.00 & 8.567 & 32.40 & 7.017 & 4.630 & 2117 & 2.417 \\
\hline $\begin{array}{l}\text { T6- Finger millet+ soybean } \\
(6: 2)\end{array}$ & 2.867 & 95.00 & 8.803 & 32.70 & 7.217 & 4.753 & 2149 & 2.633 \\
\hline $\begin{array}{l}\text { T7- Finger millet+ Black } \\
\text { gram }(4: 2)\end{array}$ & 3.217 & 105.00 & 9.677 & 34.30 & 7.900 & 5.213 & 2300 & 3.233 \\
\hline $\begin{array}{l}\text { T8 -Finger millet+ Black } \\
\text { gram }(6: 2)\end{array}$ & 3.500 & 110.00 & 9.803 & 34.80 & 8.333 & 5.460 & 2395 & 3.653 \\
\hline $\begin{array}{l}\text { T9- Finger millet+ } \\
\text { Groundnut }(4: 2)\end{array}$ & 2.920 & 97.00 & 9.200 & 33.10 & 7.420 & 4.863 & 2232 & 2.870 \\
\hline $\begin{array}{l}\text { T10- Finger millet+ } \\
\text { Groundnut }(6: 2)\end{array}$ & 3.053 & 103.00 & 9.433 & 33.50 & 7.600 & 5.103 & 2265 & 3.050 \\
\hline SEM \pm & 0.116 & 0.208 & 0.139 & 0.095 & 0.074 & 0.100 & 12.059 & 0.132 \\
\hline CD at $5 \%$ & 0.361 & 0.649 & 0.432 & 0.297 & 0.231 & 0.312 & 37.570 & 0.410 \\
\hline
\end{tabular}


Table.2 Yield and economics of finger millet as influenced by different treatments

\begin{tabular}{|c|c|c|c|c|c|c|}
\hline Treatments & $\begin{array}{l}\text { Grain yield } \\
\text { of finger } \\
\text { millet } \\
(\mathrm{kg} / \mathrm{ha})\end{array}$ & $\begin{array}{l}\text { Finger millet } \\
\text { equivalent } \\
\text { yield } \\
(\mathrm{kg} / \mathrm{ha})\end{array}$ & $\begin{array}{l}\text { Cost of } \\
\text { cultivation } \\
\text { (Rs/ha) }\end{array}$ & $\begin{array}{l}\text { Gross } \\
\text { return } \\
\text { (Rs/ha) }\end{array}$ & $\begin{array}{l}\text { Net return } \\
\text { (Rs/ha) }\end{array}$ & $\mathrm{B}: \mathrm{C}$ ratio \\
\hline T1- Finger millet ( sole) & 2017 & 2017 & 17500 & 44374 & 26874 & 1.53 \\
\hline T2- Soybean (sole) & & 1843 & 24700 & 68191 & 43491 & 1.76 \\
\hline T3 -Black gram (sole) & & 2325 & 20400 & 69750 & 49350 & 2.41 \\
\hline T4 -Groundnut (sole) & & 2302 & 30850 & 92080 & 61230 & 1.98 \\
\hline T5 -Finger millet+ soybean $(4: 2)$ & 1831 & 3521 & 24850 & 77462 & 52612 & 2.11 \\
\hline T6- Finger millet+ soybean (6:2) & 1865 & 3425 & 25300 & 75350 & 50050 & 1.97 \\
\hline $\begin{array}{l}\text { T7- Finger millet+ Black gram } \\
(4: 2)\end{array}$ & 1975 & 4233 & 24350 & 93126 & 68776 & 2.82 \\
\hline $\begin{array}{l}\text { T8 -Finger millet+ Black gram } \\
(6: 2)\end{array}$ & 2010 & 4228 & 24700 & 93016 & 68316 & 2.76 \\
\hline $\begin{array}{l}\text { T9- Finger millet+ Groundnut } \\
(4: 2)\end{array}$ & 1905 & 4013 & 26450 & 88286 & 61836 & 2.33 \\
\hline $\begin{array}{l}\text { T10- Finger millet+ Groundnut } \\
(6: 2)\end{array}$ & 1933 & 3993 & 26800 & 87846 & 61046 & 2.27 \\
\hline $\mathrm{SEM} \pm$ & 5.893 & & & & & \\
\hline CD at $5 \%$ & 18.360 & & & & & \\
\hline
\end{tabular}


However, Weight of ear head, number of fingers /ear, length of fingers/ear, number of grains/ear, test weight, was significantly high in sole crop. Among different intercroppings systems Finger millet + Black gram (6:2) row ratio were produced highest Weight of ear head, number of fingers /ear, length of fingers/ear, number of grains/ear and test weight. These results are in accordance with finding of Rathore and Gautam (2003) and Ramamoorthy et al. (2004).

\section{Grain and straw yield}

The sole crop of finger millet recorded the highest grain yield (2017 kg/ha) which was significantly superior over rest of the treatments. The grain as well as straw yield reduced considerably when intercropped with legumes in comparison to sole crop of finger millet as reported by Singh and Arya (1999) and Mitra et al. (2001). Among all the intercropping system, the maximum yield was recorded in the finger millet intercropped with blackgram followed by groundnut and soybean. However the ratio of 6:2 among all intercropping systems recorded significantly higher grain and straw yield than $4: 2$ ratio of intercropping systems.

\section{Grain equivalent yield of finger millet}

As regards the finger millet grain equivalent yield significantly highest yield $(4233 \mathrm{~kg} / \mathrm{ha})$ was observed by the treatment $\mathrm{T} 7$ where black gram was taken as intercrop in finger millet in 4:2 row proportion. But it was at par with the treatment T8 where black gram was taken as an intercrop in finger millet in 6:2 row proportions $(4228 \mathrm{~kg} / \mathrm{ha})$. Similar results were also reported by Thorat et al. (1986), Mahadkar and Khanvilkar (1988), Shankarlingappa and Hegade (1992) and Ramamoorthy et al. (2004). It indicates that it is beneficial to raise the finger millet with intercrops rather than sole crop alone.

\section{Economics}

The results clearly showed that sole groundnut recorded the highest net return than all other sole crops (Table 2). This was mainly due to high price of groundnut. However, the highest benefit/cost ratio was obtained from sole black gram due to high productivity of black gram. The lowest net return and benefit/cost ratio was obtained from sole finger millet, which might be due to low productivity of the crop.

Monetary returns (Table-2) as elucidated by net income were significantly higher in different intercropping systems as compared to sole finger millet. Looking to overall economics all legumes and finger millet with legume intercropping treatments gave significantly higher net realization over that of sole finger millet. This could be attributed to higher yield advantage under sole legumes and intercropping systems. Finger millet + Black gram (4:2) combination gave the highest net return of Rs. 68776 /ha and benefit cost ratio of 2.82 followed by finger millet + Black gram (6:2) which gave net return of Rs. 68316/ha with 2.76 benefit cost ratio which confirmed the superiority of Finger millet with black gram at 4:2 pair row ratio over other treatments. Similar results were also reported by Yadav and Jat (2005).

\section{References}

Aravazhi, E., S. Natarajan and Thambaraj, S. (1997). Economics of intercropping in chilli. South Ind. Horticul. 45:139- 194.

Bangali, M. K. (1987). Studies on pearl millet (Pennisetum americanum L.) under intercropping system at different nitrogen levels, M.Sc. (Ag.) Thesis, Sukhadia Univ. Udaipur (Raj.).

Caballero, R., Goicoechea, E. L. and Hernaiz, P. J. (1995). Forage yield and quality of common vetch and oat sown at varying 
seed ratios and seeding rates of common vetch. Field Crops Res., 41: 135-140.

Carr, P. M., Horsley, R. D. and Poland, W. W. (2004). Barley, oat and cereal-pea mixtures as dryland forages in the Northern Great Plains. Agron. J., 96: 677-684.

Diva Karan, K. (1967). Studies on age of seedlings in ragi (Eleusine coracana Gartn.). Madras Agric. J., 54(9):4-75.

Narasimha Rao, D. V., damodaram, G. and Rama Moorthy, A. K. (1963). Preliminary studies on the proper time of sowing and plant population in irrigated ragi in Chittoor district. Andhra Agric. J., 15(2):208-213.

Natarajan, S. (1992). Effect of intercrops on chilli (Capsicum annum L.) under semi dry condition, South Ind. Horticult. 40:273-276.

Rathore, S. S. and Gautam, R. C. (2003). Agro techniques to improve the productivity of pearl millet + cowpea intercropping system under dry land conditions. Ann. Agric. Res., 24: 971975.

Sadashiv, B. Nemgouda. (2004). Production potential of hybrid cotton (Gyssipium hirsutum) based vegetable intercropping systems under irrigation. M.Sc (Ag.) thesis, University of Agriculture Science, Dharwad, India.

Tiwari, Ranu. Yadav, R. S. and Kumawat, Amit. (2015). Differential Competitive ability and growth habit of pearl millet and cluster bean cultivars in intercropping system under hyper arid partially irrigated western plain zone. Ind. j. Agric. Res., 49(3): 229-234.

Yadav, G. L. and Jat, B. L. (2005). Intercropping of moth bean varieties with pearl millet for sustainable crop production in arid ecosystem. Ind. $J$. Pulse Res., 18: 252-253.

\section{How to cite this article:}

Binod Kumar and Pankaj Kumar Ray. 2020. Yield and Economics of Finger Millet with Different Legumes in Koshi Region of Bihar, India. Int.J.Curr.Microbiol.App.Sci. 9(05): 22822287. doi: https://doi.org/10.20546/ijcmas.2020.905.260 